\title{
Modernization of the Genocide Clause of the Criminal Code of the Russian Federation
}

\author{
Anatolii S. Barabash and Georgii L. Moskalev* \\ Siberian Federal University \\ 79 Svobodny, Krasnoyarsk, 660041, Russia
}

Received 04.06.2014, received in revised form 14.08.2014, accepted 20.10.2014

\begin{abstract}
The present Article brings up an issue on the necessity to modernize the disposition of Article 357 of the Criminal Code of the Russian Federation (genocide). As a reference for improvement of the genocide law, the authors used the criminal codes of some foreign countries that expanded the term of genocide under the UN Convention on the Prevention and Punishment of the Crime of Genocide signed in the year 1948. The revealed ways of improving the genocide law were critically analyzed. The inclusion of sexual assault into the list of acts of genocide along with the excessive expansion of the groups protected by the law on the abovementioned crime are negatively assessed. The recognition of a concept of cultural genocide, which is elimination of a group possessing any distinctive cultural features by liquidation of such features, is considered as a rational way of modernizing the genocide law. The analysis of Article 357 of the Criminal Code of the Russian Federation revealed that similar expansion of the "genocide" term does not contradict its core features. As a conclusion, the authors of the present Article suggest a new edition of Article 357 of the Criminal Code.
\end{abstract}

Keywords: genocide, Article 357 of the Criminal Code of the Russian Federation, foreign criminal legislation, cultural genocide, acts of genocide.

Research area: Law.

\section{Introduction}

The law on criminal liability for genocide appeared in the Criminal Code of the Russian Federation as a result of Russia's fulfilling its obligation to bring its national legislation into compliance with the clauses of the UN Convention on the Prevention and Punishment of the Crime of Genocide signed in the year 1948 (hereinafter referred to as the Convention 1948) as stated in Article $\mathrm{V}$ of the mentioned regulation. Despite the presence of some discrepancies that occurred mostly due to some errors in the process of placing the conventional features of crime of genocide into Russian criminal law, in general the definition of the crime in Article III of the Convention 1948 and Article 357 of the Criminal Code of the Russian Federation was formulated similarly. This circumstance proves the attempt of Russian legislators to provide the definition of genocide in maximum compliance with the crime definition as formulated by the international law.

At first, it is hard to reproach the legislators with the approach they selected. However, it should be remembered that by the time of enactment of the current Criminal Code of the Russian Federation, the conventional definition of

(c) Siberian Federal University. All rights reserved

* Corresponding author E-mail address: vpb2005@yandex.ru 
genocide had been existing for 48 years without any modification. At the same time, the social relations protected by the genocide law had been invaded multiple times. The Convention 1948 had no potential to meet the new challenges of socially hazardous deeds against the security of people. However, the genocide regulations adopted by the national criminal laws did have the required potential.

The foreign criminal codes that provide a genocide law different from that of the Convention 1948 are of greatest interest for the current research. They are the codes that should be consulted for the more up-to-date definitions of genocide. These are the regulations that contain the examples of modernizing the liability for genocide, consider the genocide acts that happened after the enactment of the Convention 1948. It is important to understand that the improvement of the law may only include the range of deeds covered by the term of genocide, expanded in comparison with that stated in the Convention 1948 , as the narrowing of such means the failure of the state to fulfill its obligation concerning the anti-genocide measures as announced in Articles I, V of the Convention 1948.

There are several possible options of improving the genocide law applied by different countries. Each of them requires an allencompassing review. In the process of critical analysis we may reveal the most rational and promising ways of development that may serve as a base for modernization of the genocide law in the Criminal Code of the Russian Federation.

\section{Rape as an act of genocide}

Often the term of genocide is expanded in foreign laws by expanding the range of deeds performed by the objective element but not included into the Convention 1948. Thus, according to Article 607 of the Penal Code of the Spanish Monarchy the objective element of genocide includes such feature as "sexual attack" [33]. The mentioned way of improving the law on genocide is based on certain facts. The question of regarding various ways to interfere into sexual freedom of an individual as acts of genocide has been being discussed in criminal law science for several years. It is remarked that the events that took place in the territory of former Yugoslavia (1992-1996), Rwanda (1994) and Darfur in Sudan (since 2003), besides physical elimination of representatives of these or those groups of population, were accompanied by massive rapes $[20$, p. 280]. In such cases, the rape of women belonging to the victim group, as a rule, is understood as a symbolic act of conquering the whole social community [20, p.280]. Thereby there is a social and historic base to consider rape to be an act of genocide. However, to do this, from the legal point of view, the deed needs to possess the distinctive feature of genocide, which is a hazard for the national, racial, ethnic and religious groups. Different sources express different points of view on the issue.

According to the first point of view, rape may threaten the existence of national, racial, ethnic and religious groups according to the features that are not referred to as genocide in its common understanding. The example given to prove this position is a community, where the social belonging of a child is defined by the social belonging of his father, and therefore the child conceived in a rape shall be considered to be a representative of an alien ethnic group [17, p.397]. However, the belonging to an ethnic group is determined the cultural identity of the individual. The fact of a rape does not create any obstacles for the child to adopt the culture of the ethnic group the mother belongs to. Therefore, in the current example the threat for the ethnic group is absent.

Another argument is a statement that massive rapes in the genocide process may 
directly affect the number of the group members, when the victim is intentionally killed in the process of the violent sexual act [17, p. 397]. Another situation, when the rape causes a serious physical or psychological disorder on the victim, is also possible [7; 17, p. 397]. Based on objective examples, such precedents have multiply been analyzed by international bodies of justice.

Thus, the International Criminal Tribunal for Rwanda, studying Jean-Paul Akayesu case, pointed out the possibility of considering rape and sexual attack as genocide only under such circumstances as the presence of intention and purpose of genocide and such consequences, as serious physical damage and psychological disorder [8]. The mentioned interpretation was later proven in the cases of Théoneste Bagasora [10], Clement Kayishema [9] and others. The same interpretation of the case was applied by the International Court in the case of genocide in the territory of former Yugoslavia [23].

As we can see from the international law enforcement practice, genocide by itself may not act as a way of committing genocide. To our mind, it is connected to the fact that sexual abuse does not influence the race of a person or his/her selfidentification as a member of a national, ethnical or a religious group. This action is practically unable to eliminate a national, ethnical, racial or a religious group, thereby it does not cause or create a threat of causing damage to the genocide object. It is the damage caused to the physical and psychological well-being of the victim, not the rape itself, which threatens the security of the whole group. Thereby, the expansion of the list of actions interpreted as genocide in the Penal Code of the Spanish Monarchy contradicts the core of the crime; thereby it shall not be recognized as legitimate or be applied as a way to modernize the genocide clause in the Criminal Code of the Russian Federation. For the same reason we suggest that the statements of some authors recommending to regard rape and other ways of sexual abuse as ways of committing the crime foreseen by the current edition of Art.357 of the CC RF [19, p. 149-151] should be taken critically. There is no coincidence that such authors usually do not state, which feature of the objective side of the genocide act such deeds refer to.

\section{Cultural genocide}

Another way of modernizing the genocide clause originates from the theoretic concept of this crime suggested by R. Lemkin. Besides physical elimination of social groups, the author also included the elimination of their cultural identity into the term. Among the acts eliminating the cultural identity, the author named regular destruction or withdrawal of cultural values, destruction of books in the language of the group, prohibition of using the group's native language, destruction of museums, schools, historical monuments, cultural institutions, objects of the group or prohibition of using them [3, p.404]. Before the enactment of the Convention 1948, the Decrees of the UN General Assembly also mentioned the genocide hazard for the whole humankind manifested in the loss of the cultural values significant for the social groups [21]. However, neither the Convention 1948 nor the national regulative acts on the criminal responsibility for genocide based on it, mention the destruction of cultural values as a means of committing genocide.

Among theorists, there are both followers and opponents of the cultural genocide concept. The latter insist on the fact that destruction of culture may not lead to elimination of a national, ethnical, racial or a religious group [14, p.40-41; 35]. One cannot but agree with this opinion. Very often physical liquidation of groups of people is accompanied by the destruction of their cultural objects. Thus, the fascist Germany's plan on the elimination of some Eastern European nations 
included destruction of the monuments of their material culture [12]. As we all know, the plan was fulfilled through both physical slaughter of the people and the actions targeted at the elimination of its cultural and spiritual identity, through destroying its culture [12]. All the acts performed by the fascist regime were closely interconnected, as they strived for destroying whole groups of people, making them go extinct. Obviously, the interconnection was also clear to the Revolutionary Tribunal of Cambodia which issued the verdict on the crimes committed by the "Khmers Rouges" in the country during the 70 -s of the $20^{\text {th }}$ century. The guilty were accused of genocide, including some actions on prohibition of confession, destruction of economic and cultural structures [15, p.34]. As we can see, the Tribunal expanded the concept of genocide in comparison with the Convention 1948 , having revealed the ways of liquidation of a group through destruction of its cultural and economic base. Therefore, the destruction of a group' culture deprives it of its own identity, leading to its extinction. Consequently, based on the mentioned historical facts, the concept of cultural genocide should be supported.

Among distinguished followers of the concept let us name A.N. Traynin. Based on the analysis of the crimes committed by German national-socialism, he pointed out such form of genocide as national-cultural, which is targeted at the elimination of the national culture, achievements and values of the abused people [34, p. 848]. Among other forms of genocide pointed out by the author, there are: "physical: immediate physical slaughter of the people belonging to a certain race or nation; biological: struggle against the birth of new members of the abused nation or race (preventing births, sterilization, prohibition of marriages, division of sexes, forced abortions in the case of concession)" [34, p. 847-848]. It is worth remarking that the classification shown above was more of a theoretic character, as its author had noticed the absence of some forms of national-cultural genocide among the criminal acts foreseen by the Convention 1948. This fact was criticized by the author and was referred to as a fault of the international regulating act.

Turning to the genocide forms' classification by A.N. Traynin in respect with the clause foreseeing a punishment for this crime in Russian criminal law, modern researchers suggest that Art.358 of the CC RF foresees responsibility only for the physical and biological elimination of the groups [11, p. 93]. However, this statement is not true. Particularly, causing grievous bodily harm as a way of committing genocide is not connected with the physical elimination of the people and is not targeted at preventing the birth of new members of the group. It is also true for the forced transfer of children from one group of people to another. Therefore, the named ways of committing genocide, listed in Art. 357 of the CC RF do not match the classification mentioned above.

In order to correct the fault, we suggest the following classification of means of committing genocide, based on the intention of the actions. The first class includes such deeds as murder and putting people under the conditions intended to bring them to physical elimination. These actions are intended to cause the death of the members of the groups and, as a result, the physical elimination of the communities. The second class includes the deeds targeted at the actual destruction of the group without physical elimination of its members. De-socialization of the group members in the event of grievous bodily harm, prevention of reproduction by means of forced transfer of children or preventing births are also the factors that may lead to the liquidation of the group as such, without causing any deaths to its members.

In the event of recognition, cultural genocide would be included into the second class, 
as it is intended to destroy the group of people by depriving it of its distinctive features, its identity, leading to the extinction of the group as such. Consequently, cultural genocide does not contradict the concept of genocide recognized by the regulatory acts.

Admitting the necessity to expand the term of genocide to the deeds destructing the cultural basis of people's groups, we offer the following solution. The formulation of "putting the group under the life conditions leading to physical elimination of its members" has an error. The legislator seems not to have considered the possibility of creating the life conditions targeted at actual elimination of the group as provided by Art. 357 of the CC RF. However, it also puts the security of national, ethnical, racial, or religious groups, the main immediate object of genocide, under risk. In the existing edition the term of "putting someone under certain life conditions" suggests an open list of means of physical elimination of a national, ethnical, racial or a religious group. In the regulatory act, the list of means of actual elimination of the protected groups is closed. The error may be corrected by excluding the term "physical" from the formulation of the analyzed feature. Such legislative solution leads to automatic inclusion of all the actions targeted at the destruction of the cultural basis of the group, liquidation of its identity and, consequently, actual extinction of the group, into the term of genocide. Therefore, Russian legislators may accept the cultural genocide concept supported by multiple researches since the times of the Convention 1948.

\section{List of the endangered groups}

One of the most disputed ways of improving the genocide legislation is the expansion of the list of groups protected by the regulation. The followers of this approach appeal to the historical events when the groups not mentioned in the
Convention 1948 or Art. 357 of the CC RF were exposed to genocide.

Among them there is the genocide committed by the "Khmers Rouges" regime in Cambodia in the years 1975-1979. In the struggle against "relics of the past" not only the national minorities but also religious communities, educated people, merchants, state officials, former state officials, officers and former government allies were extirpated [15, p. 34]. As we can see, the people were selected not only by their nationality and religion, but also by their social position and the ideology of their world outlook. And even though in the most cases nationality was not the determining factor, the whole deed was classified as genocide under the Decree of the People's Revolutionary Council of Cambodia on June 15, 1979. The tribunal concluded that the deeds of the "Khmers Rouges" were extremely grievous, with no analogues in the world history, and expanded the list of the protected groups suggested by the Convention 1948.

It is impossible to speak of the elimination of the groups protected by the genocide law unambiguously if it involves the events of the year 1994 in Rwanda. The fact is during the major part of the country's history the division of its population into the Hutu and the Tutsi has been based on their belonging to the class of authority or aristocracy [2, p. 103]. An individual transfer from one group into another was possible [2, $\mathrm{p}$. 103]. A. Guichaoa remarked that "All groups of Rwanda shared single national territory, spoke the same language, believed in the same myths and followed the same traditions" [35], which excluded any ethnical division of the Hutu and the Tutsi. Together with the multiple mixed marriages between the groups that have been common throughout the life of many generations, it is possible to state the total absence of any biological or cultural differences between them [22, p. 25]. 
The advantage of defining the mentioned groups as ethnic communities was proven by the special cards introduced in the mid- $20^{\text {th }}$ century, where the belonging of an individual to this or that group was referred to as ethnical, thereby excluding the possibility of switch from one group to another. As a result, the International Tribunal for Rwanda recognized the Hutu and the Tutsi as ethnic groups. However, considering the existing disputes, there was another opportunity that would lead to impossibility of recognizing the extirpation of 800 thousand Tutsis as genocide.

The events that happened in Guatemala in 1982-1983 also included the extirpation of the groups not encompassed by the genocide clause of the Convention 1948. Besides Indians, the trade unions, political opposition and people who provided any assistance to the rebels were also eliminated. Therefore, the endangered groups were defined not only by their ethnicity, but also by their ideological orientation.

Unfortunately, Russian history also has some examples of intentional elimination of the social groups outlined by the features not foreseen by the Convention 1948. So, in the process of the forced collectivization of agriculture in the USSR during 1920-1930-s, one of the trends of the state policy was the "liquidation of kulaks as a class", "dekulakization", which meant depriving wealthy peasants of their production tools, land plots and civil rights, sending them to exile to some remote regions of the country or condemning them to imprisonment in labor camps [13, p. 36]. From 5 to 15 million peasants were recognized as kulaks and therefore repressed [16, p. 35]. It is not hard to see that the acts encompassed by the genocide clauses were performed to slaughter the people selected by their economic belonging to a social group, and therefore the deed may not be classified as a crime of this kind.

The genocide law in the Criminal Code of the Russian Federation does not encompass the events mentioned above, agreeing with the list of endangered groups of the Convention 1948. This circumstance sets a question on the necessity to modernize Art. 357 of the CC RF by expanding the list of groups protected by the law. On the other hand, the historical facts mentioned above were not dismissed by some foreign legislators, causing the inclusion of some other groups, not mentioned in the Convention 1948, into the national legislation of numerous countries.

As an example, we may study Part 1 Art. 118 of Polish Penal Code as of 1997, which, besides national, ethnical, racial and religious groups, also includes political groups and groups with a different perspective on life [32]. The genocide law stated in Art. 269 of the CC of Ethiopia is also expanded by mentioning political groups [26]. Social and political groups are also mentioned in Art. 99 of the CC of Lithuania [31] and in Art. 71 of the CC of Latvia [30]. Obviously, Art. 90 of the CC of Estonia covers the groups resisting occupation to provide security of the groups of certain political convictions [25]. However, in the genocide law articles of the Criminal Codes of the Baltic countries the mentioned groups are united by another, broader feature. They are encompassed by the term of "any social group", also listed in the regulations. The list of groups endangered by genocide is expanded in Art. 127 of the Criminal Code of the Republic of Belarus just in the equal, radical way. This law, foreseeing responsibility for the crime, besides national, ethnical, racial and religious groups also covers "groups defined on the basis of any voluntary criterion" [24]. A similar formulation was used to expand the genocide law in Art.211-1 of the CC of France [28] and Art. 407 of the CC of Georgia [29]. The formulations used for modernization of the genocide law of France, Georgia and Belarus on one hand and those of the Baltic countries on the other hand, though different textually, are equal in expanding the list of groups covered 
by the law. Because any social group means the same as a group defined on the basis of any voluntary criterion, different from others in any of its features.

The expansion of the list of the groups protected by the national criminal legislation of foreign countries in Section 1 Chapter 11 of the $\mathrm{CC}$ of Finland is of special interest. This regulation completed the list including a national, ethnical, racial and a religious group with "a comparable group" [27]. With all of its originality, the formulation seems to be the least efficient of those mentioned above. It does not clarify which features are expected to be used for comparison. Perhaps, the formulation used by the Finnish legislators may be used as an example of failure in modernizing the genocide law in the national legislation.

The examples shown above illustrate the tendency of expanding the range of groups protected by the genocide laws of national legislations. However, the modernization is carried out differently in different countries, and often the groups introduced into the laws do not match with each other. Obviously, the mentioning of political groups and groups with certain life perspective in the genocide law is connected with the multiple historical examples of such groups' extirpation. Some of them have been mentioned above. However, as the history possesses lots of cases when groups determined on the basis of any other features were exposed to violence, one may set up the question on the rationality of including any social communities into the list of groups protected from genocide. For better understanding of the most preferable way of modernization, let us turn to the current doctrinal opinions on the studied issue.

First of all, it should be remarked that the expansion of the list of groups protected by the genocidelaw is opposed by anumber of researchers. Admitting the historical facts of the extirpation of groups defined by features beyond their national, ethnical, racial or religious belonging, they still claim that such cases do not mean the necessity of including new groups of people into the genocide law [35]. Agreeing with this suggestion, we still consider the studied way of improving the genocide law correct. But it is suggested that the groups protected by the genocide law are defined not only on the basis of historical experience as it is done by some researchers [4, p. 41], but also following the concept of this crime established by the Convention 1948. However, it is interpreted differently by different authors.

So, N.V. Moshenskaya supposes that "genocide means intentional crime targeted at the extirpation of a group of people defined on the basis of their belonging to some community" [16, p. 35]. Giving this definition, the author supports the expansion of the range of groups endangered by genocide to any social group. However, as fairly remarked by the critics of this opinion, this definition allows the commission of genocide of any group existing in the society, like hunters, fishermen, golf players etc. [35].

Some researchers offer using the voluntariness of participation as a criterion for determining the groups protected by the genocide law. So, it is suggested not to include the groups, the membership in which is caused by a voluntary deed, into the disposition of the genocide law [18, p. 215 ; 22, p. 15]. Such groups may be communities united by professional, economic or other interests. This criterion is rejected, first of all, by the supporters of expanding the definition of genocide by including political groups into it [5, p. 26], which, as it has been proven above, is often done in the national criminal codes of some foreign countries based on certain historical reasons. To our mind, the mentioned criterion may not be agreed upon for the reason of the genocide law's protecting the security of religious groups, the membership in which is usually based 
on the voluntary incentive of the person. Thereby, the voluntariness criterion contradicts the ideas the genocide law is based on; therefore, it may not be accepted.

Another criterion suggested as a doctrine for the determination of the groups to be protected by the genocide law, is the social significance of the group [1, p. 141]. According to the researchers suggesting the criterion, it may be defined as number, sustainability of the group, duration of its existence or any relevant role played by it [1, p. 142]. However, from our point of view, the mentioned features may not determine significance of a group and are not capable of distinguishing the groups to be protected from any others. For example, the history of the amateur hunter community counts several centuries. It includes a great number of people. As a rule, the people choosing hunting as their hobby do not change their habits, which proves the sustainability of the community. Being a community actualizing the interests of people, it plays a significant role in the life of society. We may see that the amateur hunter community matches the social significance criterion suggested by the criticized researchers. But may this argument lead us to the conclusion on the possibility of genocide of amateur hunters and, as a result, on the necessity of recognizing this group as an object of genocide? The negative answer to this question is obvious.

Having reviewed the number of groups listed both in the Convention 1948, and Art. 357 of the CC RF, one may discover that there is more they have in common than just social significance. These groups possess some unique distinctive features that identify them. In the case of religious, national and ethnical groups we speak of cultural identity. Because it is the distinctive life perspective that is used to differentiate between different religious groups, and the cultural differences that are used to differentiate between ethnos or nations. Elimination of such groups put the whole humankind under a threat, decreasing the cultural and genetic diversity of the humankind. Works by the founder of the genocide concept, R. Lemkin, witness the fact that the selection of the groups to be protected by the Convention 1948 was done according to the current logic. In his article published in 1947, Lemkin remarked that genocide "leads to special losses for the civilization, which are the cultural achievements that may only belong to some certain groups of people united by national, racial, or cultural features" [6].

As we know, those are not only national, ethnic, and religious groups that have a unique cultural identity. Thus, the extirpation of the groups with certain political perspective limits the ideological diversity just in the same way as it happens at the extirpation of a religious group. There are some unique cultural characteristics typical for some social strata, or casts in the societies with restricted or closed social mobility. There are skills and working methods specific for some professional groups, inaccessible to others. Finally, the ethnographic classifications of human communities include other groups besides national and ethnical ones, which may possess some special distinctive features. But the security of all those groups is unprotected from genocide for the reason of the strict limitation of the groups listed in the law on the responsibility foreseen for this type of crime. This defect of the Convention 1948 was inherited by Art. 357 of the CC RF. It is the Russian regulatory act that requires some legislative modernization.

All the facts demonstrated by the current research allow the authors to formulate a suggestion on the legislative improvement of Art. 357 of the CC RF. We consider it right and rational to formulate the regulation as follows: 
The actions intended for complete or grievous bodily harm, prevention of birth, forced incomplete elimination of racial, national, ethnic, transfer of two or more persons aged under 16 religious or any other groups that have any from one such group to another, or putting them cultural distinctive features by homicide of two or more members of the group or causing them under conditions for the extirpation of such a group.

\section{References}

1. Avanesian V.V. Genocide: a Criminological Research. Dissertation for the academic degree of a Candidate of Law: 12.00.08 / Avanesian Vilen Vitalyevich. Moscow, 2010. 235 p.

2. Amann D.M. Group Mentality, Expressivism, and Genocide // International Criminal Law Review. 2002. № 2. P. 93-143.

3. Arutiunian M.A. Definition of Genocide. Historical Prerequisites of the International Legal Admittance of Genocide as a Crime Against the Security of the Humankind // Aktual'nye problemy rossiyskogo prava. 2009, No.3. P. 403-414.

4. Arutiunian M.A. Definition of Genocide as a Crime. Historical Prerequisites of the International Legal Admittance of Genocide as a Crime Against the Security of the Humankind // Advokatskaia praktika. 2009, No.4. P. 38-41.

5. Bauer Y. Genocide Prevention in Historical Perspective // Politorbis. 2009. № 47. P. 25-32.

6. Bem M.V. Evolution of the Genocide Concept by R. Lemkin // Rossiyskiy iuridicheskiy zhurnal. 2013, No.6. P. 36-41. Accessible in the legal reference system "Consultant Plus".

7. Fisher S.K. Ocupation of the womb: forced impregnation as genocide // Duke law J.-Vol. 46, N 1.-P. 91-133.

8. International Tribunal for the Rwanda. Judgment Prosecutor v. Jean-Paul Akayesu (Case No. ICTR-96-4-T) of 02.11.1998 // UNICTR.ORG: official website of the International Tribunal for Rwanda. URL: http://www.unictr.org/Portals/0/Case/English/Akayesu/judgement/akay001.pdf (date of reference: 20.08.2013).

9. International Tribunal for the Rwanda. Judgment Prosecutor v. Clement Kayishema and Obed Ruzindana (Case No. ICTR-95-1-T) of 21.05.1999 // UNICTR.ORG: official website of the International Tribunal for Rwanda. URL: http://www.unictr.org/Portals/0/Case/English/kayishema/ judgement/990521_judgement.pdf (date of reference: 20.08.2013).

10. International Tribunal for the Rwanda. Judgment Prosecutor v. Théoneste Bagasora, Gratien Kabiligi, Aloys Ntabakuze, Anatole Nsengiyumva (Case No. ICTR-98-41-T) of 18.12.2008 // UNICTR. ORG: official website of the International Tribunal for Rwanda. URL: http://www.unictr.org/Portals/0/ Case/English/Bagosora/Judgement/081218.pdf (date of reference: 20.08.2013).

11. Kibal'nik A.G., Solomonenko I.G. Crimes Against Peace and Security of Humankind / supervised by A.V. Naumov. Saint Petersburg: Iuridicheskiy tsentr Press, 2004, 385 p.

12. Klebanov L.R. Criminal and Legal Security of the Cultural Sovereignty of Russia // Ugolovnoe pravo. 2008, No. 5. P. 28-34.

13. Klimchuk Ia.A. Classification and Dynamics of the De-Kulakization Methods // Mir nauki, kul'tury, obrazovaniia. 2007, No.2. P. 36-38.

14. Kniaz'kina A.K. Problems of Implementing the Conventional Genocide Norms into the CC RF // Rossiyskiy sledovatel'. 2012, No.23. P. 40-41. 
15. International Criminal Law. Academic textbook. I.P. Blishchenko [et al.], edited by V.N. Kudriavtsev. Moscow, Nauka, 1999. 264 p.

16. Moshenskaia N.V. Genocide: Historical and Legal Characteristics of the Term // Advokatskaia praktika. 2005, No.3. P. 30-35.

17. Obote-Odora A. Complicity in genocide as understood through the ICTR experience // International Criminal Law Review. 2002. № 22. P. 375-408.

18. Pankratova E.D. To the Question on the Determination of the Genocide Object // Probely v rossiyskom zakonodatel'stve. 2010, No.2. P. 214-215.

19. Pankratova E.D. Criminal and Legal Characteristics of Genocide. Dissertation for the academic degree of a Candidate of Law: 12.00.08 / Pankratova Ekaterina Dmitrievna. Moscow, 2010. $200 \mathrm{p}$.

20. Reid-Cunningham A. R. Rape as a Weapon of Genocide // Genocide Studies and Prevention. 2008. V. 3. P. 279-296.

21. Resolution of the General Assembly of the United Nations "Crime of Genocide" dated 11.12.1046 № 96(1) // UN.ORG: official webside of the General Assembly of the United Nations. URL: http:// daccess-dds-ny.un.org/doc/RESOLUTION/GEN/NR0/035/52/IMG/NR003552.pdf?OpenElement (date of reference: 10.11.2013).

22. Skuratova A.Iu. International Crimes: Modern Classification Problems. Monograph. Moscow: Infra-M, 2012. $160 \mathrm{p}$.

23. Case concerning Application of the Convention on the Prevention and Punishment of the Crime of Genocide (Bosnia and Herzegovina v. Yugoslavia) Preliminary Objections of 11.07.1996 // ICJ-CIJ.ORG: official website of the International Court of the United Nations URL: http://www.icjcij.org/docket/files/91/7349.pdf (date of reference: 20.08.2013).

24. The Criminal Code of the Republic of Belarus dated 09.07.1999 / Introduction by B.V. Volzhenkin; review by A.V. Barkov. Saint Petersburg: Iuridicheskiy tsentr Press, 2001.

25. The Criminal Code of the Republic of Estonia dated 01.09.2002 (edited on 06.12.2005) / Translated from Estonian and edited by V.V. Zapevalov. Saint Petersburg: Iuridicheskiy tsentr Press, 2005.

26. The Criminal Code of the Federal Democratic Republic of Ethiopia (Proclamation No.414/2004) // ILO.ORG: official website of the International Labor Organization. URL: http://ilo.org/dyn/natlex/ docs/electronic/70993/75092/f1429731028/eth70993.pdf (date of reference: 20.08.2013).

27. The Criminal Code of Finland (39/1889, amendments up to 927/2012 included) // FINLEX.FI: online database of up-to-date legislative and other judicial information of Finland. URL: http://finlex. fi/en/laki/kaannokset/1889/en18890039.pdf (date of reference: 20.08.2013).

28. The Criminal Code of France dated 01.03.1994 (edited on 01.01.2002) / Translated from French and introduction by N.E. Krylova; edited by L.V. Golovko, N.E. Krylova. Saint Petersburg: Iuridicheskiy tsentr Press, 2002.

29. The Criminal Code of Georgia dated 22.07.1999 (edited on 09.01.2007) // LAW.EDU.RU: Federal legal portal Iuridicheskaia Rossiia. URL: http://aw.edu.ru/norm/norm.asp?normID=1241370 (date of reference: 20.08.2013).

30. The Criminal Code of the Latvian Republic dated 01.04.1999 (edited on 01.08.2001) / Translated from Latvian by A.I. Lukashov; edited by A.I. Lukashov, E.A. Sarkisova. Saint Petersburg: Iuridicheskiy tsentr Press, 2001. 
31. The Criminal Code of the Lithuanian Republic dated 26.09.2000 (edited on 12.02.2007) / Translated from Lithuanian by V.P. Kazanskene; edited by V. Pavilonis. Saint Petersburg: Iuridicheskiy tsentr Press, 2003.

32. The Penal Code of the Republic of Poland dated 01.01.1997 (edited on 01.08.2001) / Translated from Polish by D.A. Barilovich; edited by A.I. Lukashov, N.F. Kuznetsova. Saint Petersburg: Iuridicheskiy tsentr Press, 2001.

33. The Penal Code of the Spanish Monarchy dated 01.05.1996 / Translated from Spanish by V.P. Zyrianova, L.G. Shnayder; edited by N.F. Kuznetsova, F.M. Reshetnikov. Moscow: Zertsalo, 1998.

34. Traynin A.N. Selected Works / compiled and introduced by N.F. Kuznetsova. Saint Petersburg: Iuridicheskiy tsentr Press, 2004. 898 p.

35. Vidus D.E. Question on the Groups Protected by the Convention on the Prevention and Punishment of the Crime of Genocide and Identification on the Genocide Victims // Accessible in the legal reference system "Consultant Plus". 2012, No.3. P. 16-27.

\title{
Направления модернизации нормы об уголовной ответственности за геноцид в УК РФ
}

\author{
А.С. Барабаш, Г.Л. Москалев \\ Сибирский федеральный университет \\ Россия, 660041, Красноярск, пр. Свободный, 79
}

В статье ставится вопрос о необходимости модернизащии диспозиции ст.357 УК РФ (геночид). Примерами совершенствования нормы о геноциде служат статьи уголовных кодексов ряда зарубежных стран, расширивших понятие геноцида по сравнению $c$ Конвенџией $\mathrm{OOH}$ «O предупреждении преступления геноцида и наказании за него» 1948 года. Обнаруженные пути развития нормы о геноциде подвергаются критическому анализу. Негативно оченивается включение посягательств на половую свободу в перечень способов совершения геночида, а также чрезмерное расширение охраняемых нормой об ответственности за это преступление групп. Целесообразным направлением модернизации нормы признано восприятие концепиии культурного геноиида - уничтожения любой обладающей отличительными культурными признаками группы путем ликвидации таких признаков. Анализ ст. 357 УК РФ показал, что подобное расширение понятия геноиида не будет противоречить его сущностным признакам. В заключение авторами статьи предлагается новая редакция ст. 357 УК РФ.

Ключевые слова: геночид, ст. 357 УК РФ, уголовное законодательство зарубежных стран, культурный геноцид, способы совершения геноцида.

Научная специальность: 12.00.00 - юридические науки. 